\title{
Intellectual Capital and Management Control: Human Capital Valuation and other challenges
}

\author{
Meir Russ*, Bino Catasús**
}

\begin{abstract}
In this contribution, we start discussing the definitions of intellectual capital, management control, performance measurement management, and the intersection between the research areas, closing with the identification of a few challenges. Next, human capital valuation will be briefly discussed and three major challenges and four major dilemmas will be deliberated. Finally, the six papers in this special issue will be introduced.
\end{abstract}

Keywords: Intellectual Capital, Management Control, Performance Measurement Management, Human Capital Valuation, Challenges and Dilemmas.

\section{Introduction and definitions}

Intellectual capital has become widely accepted by practitioners and academics as a major driver of value in the knowledge economy (Mouritsen \& Larsen, 2005) and is presently recognized as a robust academic field progressing toward becoming a referenced discipline (Serenko \& Bontis, 2013). Still, measuring and managing intellectual capital is a major challenge and numerous research gaps were identified in this area including a relative lack of bottom-up research of the praxis of intellectual capital (Dumay \& Garanina, 2013). This special issue ensuing from the workshop conducted by the University of Pisa in 2013 intends to respond to this challenge in the focus area of the intersection between intellectual capital and management control.

Intellectual capital could be defined in a number of ways (e.g., Petty \& Guthrie, 2000; Kim \& Taylor, 2014). Most definitions would agree it contains human, structural and relational capital aspects. Also, utilizing the knowledge,

\footnotetext{
* Professor of Management, Philip J. and Elizabeth Hendrickson Professor for Business, University of Wisconsin, Green Bay, USA. E-mail: russm@uwgb.edu.

** Professor of Accounting and Auditing, Stockholm Business School, Stockholm University, Sweden. E-mail: bino@sbs.su.se.
} 
experience, relationships and technological capacities possessed by the affirmation capitals to create organizational capabilities and sustainable competitive advantages resulting in value, is the core of intellectual capital definition (CIMA, 2001). The measuring paradigm holds a strong position in mainstream accounting and managerial literature discussing intellectual capital (Cuganesan \& Dumay, 2009) prescribing to the doctrine of "what gets measured gets managed" that underpins this functionalistic paradigm (Catasús, Ersson, Gröjer, \& Wallentin, 2007). An alternative paradigm, a learning paradigm, is presently proposed. The focus in this paradigm seems to be on the more dynamic flow and process aspects of intellectual capital as a critical factor supporting organizational future learning potential (Kujansivu \& Lönnqvist, 2008; Yu, \& Humphreys, 2013). The argument proposed is that representations of IC, be they financial or non-financial, do not suffice as a means to support management control of value creation.

Management control is an older and further established academically studied area, incorporated into the study of performance management systems. Performance management systems are defined as "the evolving formal and informal mechanisms, processes, systems, and networks used by organizations for conveying the key objectives and goals elicited by management, for assisting the strategic process and ongoing management through analysis, planning, measurement, control, rewarding, and broadly managing performance, and for supporting and facilitating organizational learning and change" (Ferreira \& Otley, 2009, p. 264). This definition is adapted to the knowledge-based economy, specifically to the systems aspects (Otley, 1999). For example, companies must add learning to their control repertoire (Herremans \& Isaac, 2005; Bititci, Garengo, Dörfler, \& Nudurupati, 2012) as well as additional related aspects (e.g., rewards systems, changes in control systems\} to render the control systems more adaptable and dynamic, and part of continuously changing social systems and networks (Ferreira \& Otley, 2009; Bititci et al., 2012).

\section{Human Capital Valuation}

One, if not the most important, aspect of intellectual capital is human capital, as mentioned above, and probably the most controversial aspect of human capital is its valuation, or measurement (Berger, Pukthuanthong, \& Roll, 2013; Celenza \& Rossi, 2012; Fulmer \& Ployhart, 2014; Savino, McGuire, \& White, 2012; Russ, 2014). Human capital valuation is an extension of conventional financial and accounting principles and tools into the praxis and research of strategic HR and labor in organizations (e.g., Lev 
\& Schwartz, 1971; Douglas, 2014) and the economy (e.g., Becker, 2009; Hamilton \& Liu, 2013). Since human capital is a multilevel construct that is studied from multiple perspectives (e.g., Crook, Todd, Combs, Woehr, \& Ketchen, 2011; Wright \& McMahan, 2011), it is not unexpected that there are a number of alternative methods for valuing human capital (e.g., Folloni \& Vittadini, 2010), resulting from the complexity and the richness of the construct of human capital (e.g., Bontis \& Fitz-enz, 2002; Poutvaara, 2008).

Russ (2013) identified three major challenges to the praxis and research of human capital valuation: the accounting, monetization, and internal markets challenges.

The first challenge is the accounting aspect of human capital valuation. Both performance measurement and accounting started with double-entry bookkeeping by Luca Pacioli in the late $13^{\text {th }}$ century. Recently, the performance measurement perspective included human resource based performance management systems (among other developments, Bititci et al., 2012) while the accounting perspective still has difficulty identifying a standardized approach for placing the value of human resources into the balance sheet (Dobija, 1998; Bullen \& Eyler, 2010; Cherian \& Farouq, 2013). By economic estimates, the value of intangibles accounts for about $80 \%$ of the value of developed nations' GDP (Nakamura, 2001). This gap, between the value of an asset and the inability the measure it, should not be acceptable, and the efforts to close it should be at least similar to what physicists are undertaking to understand the nature of black matter and black energy as driving forces of the universe (Russ, 2013).

The second challenge is the monetization aspect of human capital. The inability of the financial markets to directly monetize human (or any other intellectual) assets results in major market failure. The present legal system in developed and developing economies recognizes the value of very few intangible assets (e.g., patents, trademarks, etc.), or only in special and limited circumstances (e.g., goodwill at sale) (e.g., Corrado, Hulten, \& Sichel, 2009). Since the development of the trade-able joint-stock corporation, incorporations and intellectual property (in its different versions) are the only ways of ownership of intellectual capital which is recognized by the existing and limited legislation of intellectual assets. As such, entrepreneurship ventures should be seen as an attempt to capture and capitalize on one's human and social capital, rather than as a pursuit of business opportunity (Baumol, 2010, p. 156; Kaul, 2013). Another aspect of the limited legal and monetization options is the question of risk and insurance. Since companies (and individuals) cannot monetize knowledge as an asset, and since com- 
panies do not own (they may lease; e.g., Lev \& Schwartz, 1971) human capital, what form of insurance can they use to monetize the risk of losing human capital or keeping the human capital they have (Mäenpää \& Voutilainen, 2012; Ostaszewski, 2003; Jaaskelainen, 2011), Lambrecht and Pawlina, (2013) insinuated that companies are using cash (or negative debt) as an insurance policy to protect themselves from losing transferable human capital. Berk, Stanton, and Zechner, (2010) proposed that due to companies' need to insure firm specific knowledge, and due to lack of other alternatives, companies are taking on less debt, resulting in slower growth. This form of insurance resulted partially in increasing the amount of cash, or cash equivalents (Sánchez \& Yurdagul, 2013) while minimizing the hiring of new full-time employees by firms. Auspiciously, the financial markets recognize this issue by: offering minimal returns to financial and capital assets; offering realistically minimal, at best, insurance vehicles for intellectual assets; and probing intently for new sources of income and/or opportunities for value monetization. The intensifying pace of economic bubbles, the increasing economic, educational and political inequalities and the high level of unemployment and under-employment, particularly of the younger generation, are further indicators of a desperately needed solution for this major market failure (Russ, 2014). In a similar way to the first challenge, the gap between the value of intangible assets and the inability to monetize them, should not be acceptable.

The third challenge for human capital is the lack of effective and efficient internal (within a firm) and external markets for human capital and the continuation of using hierarchies (or other alternative solutions) instead (e.g., Coff \& Kryscynski, 2011; Williamson, 1975; Boudreau \& Ramstad, 2013). To illustrate this point, one can look into the minimal association between the compensation and value created by top CEOs (e.g., Malul \& Shoham, 2013; Murphy, 2012; Bereskin \& Cicero, 2013), women and minorities hitting the glass ceiling and leaving companies to start their own business (Morrison, White, \& Van Velsor, 1992; Saxenian, 2002), the inability of companies to find talent while unwilling or unable to train them from the inside (Kotorov \& Hsu, 2002; Camuffo, 2002), and, the need for companies to rely on open innovation for new and creative solutions when they are unable to utilize their internal R\&D despite the huge investments (Chesbrough, 2003; Spithoven, Clarysse, \& Knockaert, 2011). All this suggests that companies lack the structure, culture (specifically, the reward systems), leadership and mechanisms for developing such internal markets (Kotorov \& Hsu, 2002; Boudreau \& Ramstad, 2013) and the economy lacks the effective and efficient markets for labor and talent (Russ, 2014). 
Russ (2013) also identified four major dilemmas facing human capital valuation.

The first dilemma is whether human capital valuation can be standardized or if, by definition, human capital is unique and company specific. The notion that human capital is understood to create and support company specific, sustainable advantage is supported by a number of theories (e.g., Bontis, 1998; Gates \& Langevin, 2010) but only partially supported be research (Bontis \& Fitz-Enz, 2002; Arrighetti, Landini, \& Lasagni, 2014; Bontis \& Serenko, 2007; Yang \& Lin, 2009; Subramaniam \& Youndt, 2005). On the other hand, current accounting standards supporting standardization across companies are less than successful and only a limited number of companies are using the voluntary standards (Petty \& Guthrie, 2000; Guthrie, Petty, \& Ricceri, 2006; Gamerschlag, 2013), so the basic dilemma still stands.

The second dilemma is whether human capital (HC) is just a building block of intellectual capital (IC) but a different construct from social (SC), relational (RC) and (IC) intellectual capital (Abdulai, Kwon, \& Moon, 2012; Bontis, 1998; Subramaniam \& Youndt, 2005; Mention \& Bontis, 2013) or is IC one asset and construct that just has different parts, like HC, SC, etc. (Lev, 2001; Eisfeldt \& Papanikolaou, 2013; Ai, Croce, \& Li, 2013; Carlin, Chowdhry, \& Garmaise, 2012). The three basic building block of IC are well accepted (Edvinsson \& Malone, 1997). The support for the first position, that the three different building blocks (HC, SC, RC) should be used separately, results from the understanding that, for managerial reasons, they are very different and require different performance measures and systems (e.g., Abdulai, Kwon, \& Moon, 2012; Mention \& Bontis, 2013). On the other hand, for practical reasons, IC should be reported as one block, which is easier to measure and report from the accounting perspective (see additional discussion in Chan, 2009). Also, the three building blocks are so intertwined, moderating and mediating outcomes (e.g., Bontis \& Fitz-Enz, 2002) that separating them is deemed unpractical, so the basic dilemma still stands.

The third dilemma is whether human capital as an asset is static, more or less like a capital asset, or liquid and dynamic, like final assets and what implication this has on valuation. If static and consistent with the dominant measurement paradigm listed above, then it is easier to record, report, and study the value of an asset (e.g., Lepak \& Snell, 1999; Joia, 2000; Hussi, 2004; Sherer, 1994) but strategically, and supported by research on capabilities, it deems to be dynamic and consistent with the learning paradigm 
identified earlier (e.g., Amit \& Schoemaker, 1993; Kianto, 2007; Vargas \& Lloria, 2014).

The fourth dilemma is whether, for the purpose of valuating human capital, everyone should be considered or if just some will qualify as an asset (and who are they?) and the rest should be considered as an expense (Russ, 2014). The traditional economic (e.g,. Becker, 1962), management (e.g., Fulmer \& Ployhart, 2014), and finance (e.g., Berk, Stanton, \& Zechner, 2010) perspectives, among others, refer to all employees as human capital. A less prevalent perspective suggests that only some employees should be considered as human capital. Chen and Lin (2004) among others (e.g., Lepak \& Snell, 1999) suggested differentiating between employees that have low and high uniqueness to the firm and low and high value to the firm, and defined as human capital only the employees identified as high uniqueness-high value. Autor and Dorn (2013) suggested that for some (service) jobs, employees with lower skill sets are performing better and delivering higher value, while Gavious, Lahav, and Russ (2014) suggested that the economic context (economic cycle) might have a counterintuitive impact on the value of human capital in low-tech industries. This may suggest that what accounts for human capital should be seen as context specific, and as such, only some employees should be considered as an asset (Russ, 2014).

\section{Some present and future challenges for IC\&MC}

Finally, Serenko and Bontis (2013) identified a number of gaps in their recent survey of the current state of intellectual capital. One of the gaps identified was the lack of publishing forums for the research of intellectual capital conducted in foreign languages. Another gap identified was that the research of intellectual capital has a limited impact on the state of practice. Dumay and Garanina (2013) suggested increasing the bottom up research of the praxis of intellectual capital and using the learned insight to improve on theory and illuminate future praxes. Bititci, Garengo, Dorfler and Nudurupati (2012) identified the need for researchers to address performance measurement as a social, learning, and networked system. Greco, Ferramosca and Allegrini (2014) suggested that family firms could provide a fertile ground for the research on intellectual capital. Family firms are featured by a specific set of resources also called 'familiness', which emerges from the family influence and interactions with the company. Future research could explore whether and how the family contributes to the firm intellectual capital with resources like the commitment, the reputational and emo- 
tional long-term investment in the firm, superior knowledge of the firm operations and activities, the long-term relationships with stakeholders, such as the capital providers, the suppliers or the customers. Also, future research could investigate whether and how the family managers' background and skills influence the firm's intellectual capital, while transcending the different family generations.

This special issue closes some of those gaps and responds to some of the challenges listed above.

\section{This issue}

This special issue discusses intellectual capital and management control, and focuses on the application of the quantitative network and system dynamic research methods to the intersection of performance measurements and intellectual capital subject matter.

In the first article, Measuring and visualizing local authorities relational capital for internal control by Pierluigi Catalfo, the author develops and describes the use of territorial relational capital (TRC) in the context of public service. The research method used is social network analysis (SNA) analyzing social relationships among different parties in the context of regional socio-economic development. Territorial relational capital is a corporate asset that determines the existence of competitive potential in relation to the existence of trade relations between the different parties of socio-economic development of an area. Once the local authorities have decided on their policy choices, relational capital (RC) can contribute to the creation of suitably organized public intervention utilizing direct actions of measurement and management control. The structure of TRC should encompass at least three components: Economic RC, Socio-Institutional RC, and Knowledge. To operationalize territorial relational capital as a set of relations and active exchanges and a system of relations between parties in a territory, requires specific metrics that will determine its value. This study is conducted in the Regional Province of Caltanissetta, Italy, as requested by the Local Authority for the purpose of Policy Making. The Authority also asked for additional input regarding the broader process of adaptation of their information system to support their needs of strategic planning and of controlling the Province's business. The study analyzes the networks within and between the agriculture, trade, services, manufacturing, and tourism sectors, pointing to strong and weak ties between players, as well as to a lack of, or potential for, ties between diverse actors. The need to support the planning process of the evolution of the territories and budget- 
ary constraints is pushing local authorities to look more carefully at the monitoring requirements of intangible resources. This includes the definition and management of policies by the local authorities, as an important part of the public sector as related to improving the internal cohesion of the system as well as indication of future routes for innovation of their policies. The paper is a worthy early example of conducting an SNA analysis in the public sphere within a regional context and level of analysis. The findings of course, should also have implications for business decision makers as well as policy makers, especially in a regional context.

In the second article, Intangibles and the creation of value in network agreements: First results of an analysis of Italian SMEs, by Fabio Caputo, Barbara Livieri, and Andrea Venturelli, the authors discuss the relationships among networks of alliances and their characteristics, with the value of intangibles and financial performances of small and medium sized enterprises (SMEs). Network agreements, through cooperation, the sharing of variously configured resources, and the accumulation of knowledge, should lead to an increase in intellectual capital and assets, resulting in improved competitiveness and financial results. This logic has driven Italian legislators to introduce legislation (Law 33/2009). This law supports the establishment of network agreements, which are a form of strategic alliance, largely used for intangible purposes, especially among Italian SMEs. Using exploratory research, the authors studied the degree that the use of network agreements has contributed to expanding intangible resources in Italian firms and whether there was an association between the formation of intellectual capital and enhanced financial performance of firms during a three year period, closing a research gap they identified. The data collected from financial statements for the cross-sectional, longitudinal panel resulted in 167 firms (nodes) belonging to 42 networks. The data collected was comprised of: homogeneity of intangible resources within a network; the number of nodes in a network; size and age of firms; and financial outcome indicators, and was collected for two periods: 2009-2010 and 2010-2011. The authors found that the value of intangibles grows mostly during the later period for the older micro-enterprise and the younger SMEs, while the growth for large enterprises was minimal. Also, no association was found between the size of the network and the creation of intellectual capital. Finally, the association of alliances and intangibles with financial outcomes was found to be multifaceted. For example, the authors found that network size has a negative effect on return on equity (ROE), potentially due to the higher coordination costs required to manage large alliances, while outcomes were most positive for micro-enterprises, especially in the second 
period. To summarize, the authors conclude that alliances have a positive effect on the creation of intellectual capital, which seems to be a key factor in value creation. This paper advances our knowledge of the importance of alliances as strategic alternatives for SMEs and the impact they have on intangibles. The study also insinuates potential venues for effective policy making at a country level.

In the third article, Outlining the impact of intellectual capital accumulation and depletion processes on the performance of an insurance firm: A dynamic resource-based perspective, by Enzo Bivona, the author develops a conceptual dynamic framework of accumulation and depletion processes of intellectual capital and their effect on firm performance, utilizing system dynamic methodology. The paper makes explicit the associations between policy levers, strategic resources, drivers, end-results and performance indicators employing the dynamic resource-based perspective, while complementing the system dynamics methodology with the resource based perspective. The system dynamics methodology acknowledges explicit causeand-effect relationships between the researched variables and facilitates the construction of simulation models. Such models assist decision makers in exploring the outcomes of applying alternative strategies to offerings of strategic intellectual resources, and in developing shared mental models. The paper applies the model to an insurance company. In this industry, human resources have a robust impact on customer satisfaction, loyalty, and purchasing behavior. The author tested the model by using an empirical case study. Data was collected using documentary analysis, personnel interviews, and half-day workshops with key company personnel. Next, explicit relationships between policy levers, strategic resources, drivers, endresults, and performance indicators were identified and represented in the form of a stock-and-flow diagram. Lastly, the model was validated and tested with key personnel. The resulting model documents a dynamic system in which allocating business resources to intellectual capital causes accumulation and depletion processes over time, and shows how such assets are interconnected with critical success factors which may enable the firm to build a sustainable competitive advantage. The paper also illustrates the potential benefits of using a simulation model to support top management learning processes in planning, managing, and controlling alternative intellectual capital dynamic investment policies. This paper is a major contribution to the literature discussing the dynamic aspects of intellectual capital by incorporating a novel methodology that has not only major research contributions, but also, potentially creates a tool for training of top level executives. 
The fourth article, Combining different components of intellectual capital within clinical teams by Francesca Grippa, John Bucuvalas and Peter Gloor proposes a framework for integrating traditional key performance indicators, such as the quality of the service provided, employee turnover reduction, and publications within pediatric clinical care teams with integrated intellectual capital metrics, by using social network analysis (SNA). The study incorporates research on team structure and team communication within a more inclusive framework based on intellectual capital measurement. The authors first analyze a number of intellectual capital methods and maps them on the four dimensions of the Balanced Scorecard, into the intellectual capital's building blocks (human, social and structural), and also into the financial focus. This discussion is followed by a brief review of the knowledge management and intellectual capital literature in the context of healthcare. Next, the authors integrate the SNA methodology with traditional Balanced Scorecard and intellectual capital methods, including a discussion of the methodology used to identify the most relevant hybrid indicators. This is followed by the presentation of the context of this case, the Liver Transplant clinical pediatric care team working with chronically ill children who have undergone liver transplantation, and describes the application of the framework and indicators for the specific case in hand as an illustration of the methodology developed. Data was collected from 35 members of the team, who exchanged 401 emails over a 1-year period, and their academic publications, and later compared with another team, using the SNA methodology to collect network indicators (e.g. density, actors' centralities). This data was later associated with publications and supported the creation of a new hybrid indicator by the author. A number of specific findings are discussed as well. For example, the author found a negative association between the number of external publications and the actor betweenness centrality within the core team, using the "intra-group" communication as an indicator for the centrality. The authors conclude the paper by suggesting that the social network perspective presented, contributes to the understanding of the evolution of social capital over time, potentially providing for a better understanding of the team and organization's dynamics and their associations with outcomes, complementing the traditional static intellectual capital and Balanced Scorecard frameworks. This paper is a significant addition to the study of knowledge management and intellectual capital in the healthcare sector, where quality of service translates into life and death outcomes, at the individual, team, and organizational level of analysis.

In the fifth paper, Maurizio Massaro, Filippo Zanin and Roland Bardy 
presents a study of Extrogens. Extrogens is a collaboration project between a large multi-national and a small Italian firm. The authors set out to identify how knowledge sharing can be controlled and managed in order to have successful collaborations. The argument of the paper is that although traditional accounting and management control techniques (such as budgets, goals, strategies, etc.) do play an important part in laying the ground of a collaborative milieu, it does not suffice. That is, although common practices, such as establishing goals and measuring the results in comparison to the goals, should be present, such a functionalistic approach may indeed risk the whole project. Instead, Massaro et al (this issue), propose that success comes from creating a common behavior, spreading core values and creating a dialogue approach. Also, aligning to Hedberg and Jönsson's suggestion about creating a semi-confusing management control system, the authors bring forward the importance of a reflective approach by realizing and accepting the complexity and the different logics that are present at the same time. The paper contributes to Simons' (1995) model about management control levers by arguing that some are more important than others in collaborations of this sort.

In the last paper of this special issue, Maria Serena Chiucchi, Marco Giuliani and Stefano Marasca present a study of the relationship between design, implementation, and use of IC measurements. The contribution of this paper rests on a study of the organization Alpha and builds on a longitudinal study of the challenges an organization has with the different phases of IC measurement and IC management. The paper reflects on the fact that design, implementation, and use are inter-connected but are not the same thing. That is, it is not ostensively true that design leads to implementation which leads to use of the IC measurements. Instead, the authors argue that the first phase, design, has to do with delimiting the space in which the organization operates. It configures artifacts such as IT in a different way than e.g. "pure" cost-information does. For Alpha, it was a learning process by which e.g. competence loss became a reality. In the second phase, implementation, management had to step forward and prioritize measurements, i.e. which measurements are important and which are not? This is an arduous process, and for Alpha, the IC report included no less than 180 measurements. This may indeed lead to information overflow, but for Alpha the numbers made it possible to talk about value creation in another way. Still, in phase three, Chiucchi et al. (this issue) show that not all numbers are used. This is an interesting finding since it gives rise to new questions about in which times and places, or with what allies, IC numbers matter? Management, it seems, wants to use IC measurement not only as a 
learning device but also as a technology for understanding cause and effect as well as value. The question is whether IC indicators can do all these things and can they all be done at the same time?

We hope you will agree that this special issue is a valuable academic resource, and you will consider submitting a paper to the journal, referencing appropriate papers in your own work, and promoting the journal among your colleagues.

\section{Acknowledgement}

The articles herein were presented at the Controlling and Reporting for Intangibles workshop in Pisa, Italy, July 11-12, 2013. The authors thank Prof. Luciano Marchi for inviting them to be the keynote speakers and for chairing the workshop. They also thank Giulio Greco and Maria Serena Chiucchi for their help in organizing the conference and their editorial assistance with this special issue. Each article received external, blind review in addition to our reviews. The first author thanks Kelly Anklam for her assistance in editing this introduction, and also wishes to thank the Frederick E. Baer Professorship in Business at UWGB for partial financial support.

\section{References}

Abdulai M.S., Kwon Y., \& Moon J. (2012), Intellectual capital and firm performance: An empirical study of software firms in West Africa, African Journal of Information Systems, 4(1), pp. 23-36.

Ai H., Croce M.M., \& Li K. (2013), Toward a quantitative general equilibrium asset pricing model with intangible capital, Review of Financial Studies, 26(2), pp. 491-530. Doi: 10.1093/rfs/hhs121.

Amit R., \& Schoemaker P.J. (1993), Strategic assets and organizational rent, Strategic Management Journal, 14(1), pp. 33-46. Doi: 10.1002/smj.4250140105.

Arrighetti A., Landini F., \& Lasagni A. (2014), Intangible assets and firm heterogeneity: Evidence from Italy, Research Policy, 43(1), pp. 202-213. Doi: 10.1016/j.respol.2013.07.015.

Autor D., \& Dorn D. (2013), The growth of low-skill service jobs and the polarization in the United States, American Economic Review, 103(5), pp. 1553-1597. Doi: 10.1257/aer.103.5.1553.

Baumol W.J. (2010), The microtheory of innovative entrepreneurship, Princeton, NJ, Princeton University Press.

Becker G.S. (1962), Investment in human capital: A theoretical analysis, The Journal of Political Economy, 70(5), pp. 9-49. Doi: 10.1086/258724. 
Becker G.S. (2009), Human capital: A theoretical and empirical analysis, with special reference to education, Chicago, IL, University of Chicago Press.

Bereskin F.L., \& Cicero D.C. (2013), CEO compensation contagion: Evidence from an exogenous shock, Journal of Financial Economics, 107(2), pp. 477-493.

Berger D., Pukthuanthong K., \& Roll R. (2013), On valuing human capital and relating it to macro-economic conditions. Available at SSRN 2373371.

Berk J.B., Stanton R., \& Zechner J. (2010), Human capital, bankruptcy, and capital structure, The Journal of Finance, 65(3), pp. 891-926. Doi: 10.1111/j.15406261.2010.01556.x.

Bititci U., Garengo P., Dörfler V., \& Nudurupati S. (2012), Performance measurement: Challenges for tomorrow, International Journal of Management Reviews, 14(3), pp. 305-327. Doi: 10.1111/j.1468-2370.2011.00318.x.

Bontis N. (1998), Intellectual capital: An exploratory study that develops measures and models, Management Decision, 36(2), pp. 63-76. Doi: 10.1108/00251749810204142.

Bontis N., \& Fitz-Enz J. (2002), Intellectual capital ROI: A causal map of human capital antecedents and consequents, Journal of Intellectual Capital, 3(3), pp. 223-247. Doi: 10.1108/14691930210435589.

Bontis N., \& Serenko A. (2007), The moderating role of human capital management practices on employee capabilities, Journal of Knowledge Management, 11(3), pp. 31-51. Doi: $10.1108 / 13673270710752090$.

Boudreau J.W., \& Ramstad P.M. (2013), Beyond HR: The new science of human capital. Boston, MA, Harvard Business Press.

Bullen M.L., \& Eyler K.A. (2010), Human resource accounting and international developments: Implications for measurement of human capital, Journal of International Business \& Cultural Studies, 3(3), pp. 1-16.

Camuffo A. (2002), The changing nature of internal labor markets, Journal of Management and Governance, 6(4), pp. 281-294. Doi: 10.1023/A:1021230525924.

Carlin B.I., Chowdhry B., \& Garmaise M.J. (2012), Investment in organization capital, Journal of Financial Intermediation, 21(2), pp. 268-286. Doi: 10.1016/j.jfi.2011.08.001.

Catasús B., Ersson S., Gröjer J.E., \& Wallentin, F.Y. (2007), What gets measured gets... on indicating, mobilizing and acting, Accounting, Auditing \& Accountability Journal, 20(4), pp. 505-521. Doi: 10.1108/09513570710762566.

Celenza D., \& Rossi F. (2012), The human capital valuation in IC paradigm: An empirical proposal, China-USA Business Review, 11(11), pp. 1517-1533.

Chan K.H. (2009), Impact of intellectual capital on organisational performance: An empirical study of companies in the Hang Seng Index (Part 1), The Learning Organization, 16(1), pp. 4-21. Doi: 10.1108/09696470910927650.

Chen H.M. and Lin, K.J. (2004), The role of human capital cost in accounting, Journal of Intellectual Capital, 5(1), pp. 116-130. Doi: 10.1108/14691930410512950.

Cherian J., \& Farouq S. (2013), A review of human resource accounting and organizational performance, International Journal of Economics \& Finance, 5(8), pp. 74-83.

Chesbrough H.W. (2003), Open innovation: The new imperative for creating and profiting from technology, Boston, MA, Harvard Business Press.

CIMA (2001), Managing the intellectual capital within today's knowledge based organizations. Technical Briefing, CIMA, London.

Coff R., \& Kryscynski D. (2011), Invited editorial: Drilling for micro-foundations of human capital-based competitive advantages, Journal of Management, 37(5), pp. 1429-1443. Doi: 10.1177/0149206310397772. 
Corrado C., Hulten C., \& Sichel D. (2009), Intangible capital and US economic growth, Review of Income and Wealth, 55(3), pp. 661-685. Doi: 10.1111/j.14754991.2009.00343.x.

Crook T.R., Todd S.Y., Combs J.G., Woehr D.J., \& Ketchen D.J. (2011), Does human capital matter? A meta-analysis of the relationship between human capital and firm performance, Journal of Applied Psychology, 96(3), pp. 443-456. Doi: 10.1037/a0022147.

Cuganesan S. \& Dumay J.C. (2009), Reflecting on the production of intellectual capital visualisations, Accounting, Auditing \& Accountability Journal, 22(8), pp. 1161-1186. Doi: 10.1108/09513570910999274.

Dobija M. (1998), How to place human resources into the balance sheet?, Journal of Human Resource Costing \& Accounting, 3(1), pp. 83-92. Doi: 10.1108/eb029044.

Douglas B. (2014), Human capital assets on the balance sheet, Available at SSRN 2398575.

Dumay J., \& Garanina T. (2013), Intellectual capital research: A critical examination of the third stage, Journal of Intellectual Capital, 14(1), pp. 10-25. Doi: 10.1108/14691931311288995.

Edvinsson L. \& Malone M.S. (1997), Intellectual capital: Realizing your company's true value by finding its hidden brainpower, New York, NY, Harper Business.

Eisfeldt A.L., \& Papanikolaou D. (2013), Organization capital and the cross-section of expected returns, The Journal of Finance, 68(4), pp. 1365-1406. Doi: 10.1111/jofi.12034.

Ferreira A., \& Otley D. (2009), The design and use of performance management systems: An extended framework for analysis, Management Accounting Research, 20(4), pp. 263-282. Doi: 10.1016/j.mar.2009.07.003.

Folloni G., \& Vittadini G. (2010), Human capital measurement: A survey, Journal of Economic Surveys, 24, pp. 248-279. Doi: 10.1111/j.1467-6419.2009.00614.x.

Fulmer I.S., \& Ployhart R.E. (2014), “Our most important Asset” A multidisciplinary/multilevel review of human capital valuation for research and practice, Journal of Management, 40(1), pp. 161-192. Doi: 10.1177/0149206313511271.

Gamerschlag R. (2013), Value relevance of human capital information, Journal of Intellectual Capital, 14(2), pp. 325-345. Doi: 10.1108/14691931311323913.

Gates S., \& Langevin P. (2010), Human capital measures, strategy, and performance: HR managers' perceptions, Accounting, Auditing \& Accountability Journal, 23(1), pp. 111132. Doi: 10.1108/09513571011010628.

Gavious I., Lahav Y, \& Russ M. (2014), Does the value of company-specific human capital depend on the state of the economy? Paper submitted to the Journal of Contemporary Accounting \& Economics.

Greco G., Ferramosca S., \& Allegrini M. (2014), Exploring intellectual capital in family firms, Journal of Learning and Intellectual Capital, forthcoming. Doi: 10.1504/IJLIC.2014.060802.

Guthrie J., Petty R., \& Ricceri F. (2006), The voluntary reporting of intellectual capital: Comparing evidence from Hong Kong and Australia, Journal of Intellectual Capital, 7(2), pp. 254-271. Doi: 10.1108/14691930610661890.

Hamilton K., \& Liu G. (2013), Human capital, tangible wealth, and the intangible capital residual, World Bank Policy Research Working Paper, (6391).

Hedberg B., \& Jönsson S. (1978), Designing semi-confusing information systems for organizations in changing environments, Accounting, Organizations and Society, 3(1), pp. 4764. Doi: 10.1016/0361-3682(78)90006-5.

Herremans I.M., \& Isaac R.G. (2005), Management planning and control: Supporting knowledge-intensive organizations, The Learning Organization, 12(4), pp. 313-329. Doi: 10.1108/09696470510599109. 
Hussi T. (2004), Reconfiguring knowledge management - Combining intellectual capital, intangible assets and knowledge creation, Journal of Knowledge Management, 8(2), pp. 36-52. Doi: 10.1108/13673270410529091.

Jaaskelainen A. (2011), How to measure and manage the risk of losing key employees?, International Journal of Learning and Intellectual Capital, 8(1), pp. 63-75. Doi: 10.1504/IJLIC.2011.037359.

Joia L.A. (2000), Measuring intangible corporate assets: Linking business strategy with intellectual capital, Journal of Intellectual Capital, 1(1), pp. 68-84. Doi: $10.1108 / 14691930010371636$.

Kaul I. (2013), Global public goods a concept for framing the post-2015 agenda? German Development Institute Discussion paper 2/2013, Bonn. Available at http://www.diegdi.de/uploads/media/DP_2.2013.pdf.

Kianto A. (2007), What do we really mean by the dynamic dimension of intellectual capital?, International Journal of Learning and Intellectual Capital, 4(4), pp. 342-356. Doi: 10.1504/IJLIC.2007.016332.

Kim S.H., \& Taylor D. (2014), Intellectual capital vs the book-value of assets: A valuerelevance comparison based on productivity measures, Journal of Intellectual Capital, 15(1), pp. 65-82. Doi: 10.1108/JIC-04-2013-0048.

Kotorov R., \& Hsu E. (2002), A road-map for creating efficient corporate internal labor markets, Career Development International, 7(1), pp. 37-46. Doi: 10.1108/13620430210414865.

Kujansivu P., \& Lönnqvist A. (2008), Business process management as a tool for Intellectual Capital Management, Knowledge and Process Management, 15(3), pp. 159-169. Doi: 10.1002/kpm.307.

Lambrecht B.M., \& Pawlina, G. (2013), A theory of net debt and transferable human capital, Review of Finance, 17(1), pp. 321-368. Doi: 10.1093/rof/rfs011.

Lepak D.P., \& Snell S.A. (1999), The human resource architecture: Toward a theory of human capital allocation and development, Academy of Management Review, 24(1), pp. 31-48. Doi: 10.5465/AMR.1999.1580439.

Lev B. (2001), Intangibles: Management, measurement, and reporting, Washington, DC, Brookings Institution Press.

Lev B., \& Schwartz A. (1971), On the use of the economic concept of human capital in financial statements, Accounting Review, 46(1), pp. 103-112.

Mäenpää I., \& Voutilainen R. (2012), Insurances for human capital risk management in SMEs, VINE, 42(1), pp. 52-66. Doi: 10.1108/03055721211207761.

Malul M., \& Shoham A. (2013), The salaries of CEOs: Is it all about skills?, Journal of Economics and Business, 67, pp. 67-76. Doi: 10.1016/j.jeconbus.2013.03.003.

Mention A.L., \& Bontis N. (2013), Intellectual capital and performance within the banking sector of Luxembourg and Belgium, Journal of Intellectual Capital, 14(2), pp. 286-309. Doi: 10.1108/14691931311323896.

Morrison A.M., White R.P., \& Van Velsor E. (Eds.) (1992), Breaking the glass ceiling: Can women reach the top of America's largest corporations?, Reading, MA, AddisonWesley.

Mouritsen J., \& Larsen H.T. (2005), The 2nd wave of knowledge management: The management control of knowledge resources through intellectual capital information, Management Accounting Research, 16(3), pp. 371-394. Doi: 10.1016/j.mar.2005.06.006.

Murphy K. (2012), Executive compensation: Where we are, and how we got there, in Harris M., Constantinides G.M. and Stulz R.M. (Eds.), Handbook of the Economics of Finance, forthcoming, Amsterdam, Elsevier. 
Nakamura L. (2001), What is the U.S. gross investment in intangibles? (At least) one trillion dollars a year!, Federal Reserve Bank of Philadelphia, Working Paper no. 01-15.

Ostaszewski K. (2003), Is life insurance a human capital derivatives business?, Journal of Insurance Issues, 26(1), pp. 1-14.

Otley D. (1999), Performance management: A framework for management control systems research, Management Accounting Research, 10(4), pp. 363-382. Doi: 10.1006/mare.1999.0115.

Petty R., \& Guthrie J. (2000), Intellectual capital literature review: Measurement, reporting and management, Journal of Intellectual Capital, 1(2), pp. 155-176. Doi: 10.1108/14691930010348731.

Poutvaara P. (2008), On human capital formation with exit options: Comment and new results, Journal of Population Economics, 21(3), pp. 679-684. Doi: 10.1007/s00148-0060129-0.

Russ M. (2013), Human capital valuations: The challenges and the dilemmas. Keynote presentation at the Controlling and Reporting for Intangibles workshop in Pisa, Italy, July $11-12$.

Russ M. (2014), Introduction - Is human capital an asset in more than one market?, in Russ M. (Ed.), Perspectives on human capital and assets: Building the foundation for a multidisciplinary, multi-level theory. New York, NY, Palgrave-MacMillan. Forthcoming.

Sánchez J.M., \& Yurdagul E. (2013), Why are corporations holding so much cash?, Federal Reserve Bank of St. Louis’ The Regional Economist, 21(1), pp. 5-8.

Savino D.M., McGuire K.S., \& White K.M. (2012), Human asset measurement: A comparison of the artifact-based approach versus input methods, Journal of Management Policy \& Practice, 13(1), pp. 39-45.

Saxenian A. (2002), Silicon Valley's new immigrant high-growth entrepreneurs, Economic Development Quarterly, 16(1), pp. 20-31. Doi: 10.1177/0891242402016001003.

Serenko A., \& Bontis N. (2013), Investigating the current state and impact of the intellectual capital academic discipline, Journal of Intellectual Capital, 14(4), pp. 476-500. Doi: 10.1108/JIC-11-2012-0099.

Sherer P.D. (1994), Leveraging human assets in law firms: Human capital structures and organizational capabilities, Industrial and Labor Relations Review, 48, pp. 671-691. Doi: $10.2307 / 2524350$.

Simons R. (1995), Levers of control: How managers use innovative control systems to drive strategic renewal, Boston, MA, Harvard Business School Press.

Spithoven A., Clarysse B., \& Knockaert M. (2011), Building absorptive capacity to organise inbound open innovation in traditional industries, Technovation, 31(1), pp. 10-21. Doi: 10.1016/j.technovation.2010.10.003.

Subramaniam M., \& Youndt M.A. (2005), The influence of intellectual capital on the types of innovative capabilities, Academy of Management Journal, 48(3), pp. 450-463. Doi: 10.5465/AMJ.2005.17407911.

Vargas M.N., \& Lloria M.B. (2014), Dynamizing intellectual capital through enablers and learning flows, Industrial Management \& Data Systems, 114(1), pp. 2-20. Doi: 10.1108/IMDS-04-2013-0190.

Williamson O. E. (1975), Markets and hierarchies: Analysis and Antitrust Implications. New York, NY: Free Press.

Wright P.M., \& McMahan G.C. (2011), Exploring human capital: Putting human back into strategic human resource management, Human Resource Management Journal, 21(2), pp. 93-104. Doi: 10.1111/j.1748-8583.2010.00165.x. 
Yang C.C., \& Lin C.Y.Y. (2009), Does intellectual capital mediate the relationship between HRM and organizational performance? Perspective of a healthcare industry in Taiwan, The International Journal of Human Resource Management, 20(9), pp. 1965-1984. Doi: 10.1080/09585190903142415.

Yu A., \& Humphreys P. (2013), From measuring to learning? - Probing the evolutionary path of IC research and practice, Journal of Intellectual Capital, 14(1), pp. 26-47. Doi: 10.1108/14691931311289002. 